\title{
SELECTION OF ENTOMOPATHOGENIC FUNGI TO CONTROL Varroa destructor (Acari: Varroidae)
}

\author{
Marta Rodríguez ${ }^{*}$, Marcos Gerding ${ }^{1}$, and Andrés France ${ }^{1}$
}

\begin{abstract}
The aim of this work was select entomopathogenic fungi tolerant to temperatures inside the brood area of honey bees (Apis mellifera) for to control Varroa destructor. For this purpose, 50 Beauveria bassiana (Balsamo) Vuillemin and 48 Metarhizium anisopliae (Metschn.) Sorokin isolates were evaluated at 30 and $35^{\circ} \mathrm{C}$. For each isolate, colony discs of $5 \mathrm{~mm}$ with mycelium were placed in the center of a Petri dish with Sabouraud dextrose agar (SDA) medium. The dishes were incubated at 30 and $35^{\circ} \mathrm{C}$, without light. Radial growth of each colony was measured daily. All the B. bassiana and M. anisopliae isolates presented a lineal growth rate at a temperature of $30^{\circ} \mathrm{C}$. However, at $35^{\circ} \mathrm{C}$, most of the isolates did not grow, except three $B$. bassiana and $14 M$. anisopliae isolates $(\mathrm{P}<0.001)$. These isolates were selected to evaluate the pathogenicity on $V$. destructor by applying a suspension of $10^{7} \mathrm{conidia}_{\mathrm{mL}}^{-1}$. The most effective isolate was M. anisopliae Qu-M845 ( $\mathrm{P}=0.0033)$ which produced $85 \%$ mortality. The pathogenic capacity of this isolate on $V$. destructor and its tolerance to hive conditions allows us to consider this strain as an alternative to control this pest.
\end{abstract}

Key words: biological control, entomopathogenic fungi, Varroa destructor, varroasis, entomopathology.

\section{INTRODUCTION}

The Varroa destructor (Acari: Varroidae) (Anderson and Trueman, 2000) mite, an ectoparasite of the honey bee (Apis mellifera; Hymenoptera: Apidae), is considered as a very serious pest affecting apiarists worldwide, and if not controlled can cause losses of up to $100 \%$ of the bee colonies (Calderone, 1999). Until now, control of this pest has been based on chemical acaricides which in turn affect production costs, toxic residue content, and resistance development (Melathopoulos et al., 2000).

A partial or total alternative to the use of chemical acaricides is the biological control of varroa which could be part of an integrated management system of the pest. Research of natural enemies against mites phylogenetically related with varroa point out the use of entomopathogenic fungi as a promising alternative (Chandler et al., 2001). Indeed, Chandler et al. (2000) reported the susceptibility of $V$. destructor to infection by Beauveria bassiana (Balsamo) Vuillemin and Metarhizium anisopliae (Metschn.) Sorokin fungi when

'Instituto de Investigaciones Agropecuarias INIA, Av. Vicente Méndez 515, Chillán, Chile. *Corresponding author

(mrodrigu@inia.cl).

Received: 02 November 2007.

Accepted: 18 April 2008. the mites were placed on these colonies. Kanga et al. (2003) found a highly pathogenic $M$. anisopliae isolate for $V$. destructor, reaching control levels in field assays similar to those obtained with fluvolinate acaricide 42 days after its application.

Although the fungi presented the advantages of easy manipulation, adaptation to different environments, specificity, and penetration directly through the tegument of the host (Lecuona et al., 1996), to achieve successful results, environmental conditions to which they will be exposed must be considered since these can influence germination and subsequent host colonization by the pathogen (Alves, 1998). One of the most important abiotic factors for the entomopathogenic fungi is temperature since it affects its metabolism by altering the production processes of enzymes, toxins, spore germination, development of the germinative tube, penetration, colonization, and reproduction (Alves, 1998).

Temperatures in bee colonies can be a determinant in the effectiveness of any biological control agent for varroa. Summer temperatures in the colony brood area are usually maintained between 32 and $37^{\circ} \mathrm{C}$ while in the rest of the beehive vary from 28 to $33{ }^{\circ} \mathrm{C}$. In winter, in temperate regions, temperature is maintained between 20 and 30 ${ }^{\circ} \mathrm{C}$ (Chandler et al., 2001). Le Conte et al. (1990) point out that optimal temperature for the development of $V$. 
destructor is between 32.5 and $33.4{ }^{\circ} \mathrm{C}$ which corresponds to the bee brood temperature. On the other hand, the optimal temperature for growth of most Hyphomycetes fungi, order in which the $M$. anisopliae and B. bassiana species belong, is between 20 and $25^{\circ} \mathrm{C}$ with infections and pathogenesis that occur at temperatures between 15 and $30{ }^{\circ} \mathrm{C}$. Over $30{ }^{\circ} \mathrm{C}$, vegetative growth of most Hyphomycetes species is inhibited and usually ceases at $37^{\circ} \mathrm{C}$ (Inglis et al., 2006).

The objective of this research study was to select Metarhizium anisopliae var. anisopliae and Beauveria bassiana isolates for their capacity to grow at temperatures between 30 and $35{ }^{\circ} \mathrm{C}$ and evaluate the pathogenicity of the selected isolates on Varroa destructor to control this pest.

\section{MATERIALS AND METHODS}

\section{Isolate selection and multiplication}

Isolates, $50 \mathrm{~B}$. bassiana and $48 \mathrm{M}$. anisopliae var. anisopliae, were selected from the entomopathogenic collection of fungi from the Centro Tecnológico de Control Biológico del Instituto de Investigaciones Agropecuarias INIA, Chillán, Chile which are stored as monosporic cultures at $-198{ }^{\circ} \mathrm{C}$ in liquid nitrogen. Each isolate was sown by taking conidia with a bacteriological loop. Conidia were superficially scattered onto the nutritive medium of Sabouraud dextrose agar (SDA) contained in Petri dishes $90 \mathrm{~mm}$ in diameter. The dishes were incubated at $25^{\circ} \mathrm{C}$ for 2 or 3 days.

\section{Evaluation of radial growth}

Cultures were carried out and, before observing conidia development, $5 \mathrm{~mm}$ diameter discs with agar plus mycelium were extracted from the colony edge growth with a lab scoop. These discs were placed in the center of the Petri dishes with SDA medium and the mycelium in contact with the nutritive medium. Dishes were incubated in incubation chambers in the dark at temperatures of 30 and $35^{\circ} \mathrm{C}$. Colony radial growth was recorded periodically for 18 days, measuring the growth radius from the center of the colony in four equidistant radii previously marked on the bottom of each dish.

The experimental unit corresponded to a Petri dish. The experimental design was completely randomized with three replicates for each isolate and temperature treatment. Analysis of variance and medium separation was carried out with the Tukey multiple comparison test.

\section{Growth rate}

Radial growth data were expressed as growth $(\mathrm{mm})$ over time. Growth rate for each isolate and temperature was calculated from the linear regressions of each replicate which corresponded to the slope of the regression (Ouedraogo et al., 1997). Different growth rates were compared on day 18 postsowing.

\section{Pathogenicity tests}

Isolates were selected for their growth at temperatures of 30 and $35{ }^{\circ} \mathrm{C}$ (Figures 1 and 2). In this way, $14 \mathrm{M}$. anisopliae and three $B$. bassiana isolates were cultured by means of sowings in Petri dishes with papa dextrose agar, and were incubated at $25^{\circ} \mathrm{C}$ until fungal sporulation. Conidia were harvested from the surface of the culture; a suspension was carried out in sterile distilled water with $1 \%$ Tween 80 at $0.1 \%$ and the conidia were disintegrated with a gyratory shaker. Conidia concentration was determined with a Neubauer (BOECO, Neubauer, Germany) counting chamber.

Varroa females were collected from the infested beehives and transferred to plastic chambers with blotting paper at the bottom. Suspensions of $10^{7}$ conidia $\mathrm{mL}^{-1}$ from each isolate were applied to the chambers by means of a Potter pulverization tower. Varroa treated only with the distilled water solution and Tween 80 made up the control. Immediately after treatment, varroa were placed on drone pupas maintained in $1 \mathrm{~mL}$ plastic tubes with cotton wool in the top, and then incubated at $25-30{ }^{\circ} \mathrm{C}$ in the dark for 10 days. Mortality of the mites and mycosis were recorded daily. Dead varroa were transferred to humid chambers and incubated at $25^{\circ} \mathrm{C}$ to observe the possible development of mycelia and conidia.

The experimental design was completely randomized with 17 isolates as treatments, three replicates, and an experimental unit consisted of 10 varroa. Results were subjected to analysis of variance after angular transformation, and the means compared with the Tukey test $(\mathrm{P} \leq 0.01)$.

\section{RESULTS AND DISCUSSION}

\section{Evaluation of radial growth}

All evaluated $B$. bassiana isolates presented growth at $30{ }^{\circ} \mathrm{C}$. The colony extension rate varied from 0.043 to $1.99 \mathrm{~mm} \mathrm{~d}^{-1}$ with the greatest development in the $\mathrm{Qu}-$ B323 isolate followed by Qu-B910, Qu-B392, and Qu$\mathrm{B} 389$ in which there were no differences $(\mathrm{P}<0.0001)$ (Figure 1). At $35^{\circ} \mathrm{C}, 14$ of the 50 isolates presented some degree of development in their colonies, of which QuB303 was the best $(\mathrm{P}<0.0001)$ followed by Qu-910 and Qu-B323 (Figure 1). In spite of the fact that the growth rate of the best isolate at $35^{\circ} \mathrm{C}$ did not exceed $0.5 \mathrm{~mm} \mathrm{~d}^{-1}$, it was similar to that observed at $30{ }^{\circ} \mathrm{C}$, thus indicating tolerance in this temperature range. Meanwhile, in the other isolates, a marked reduction at a greater temperature were observed, characteristic that concurs with Tefera and 


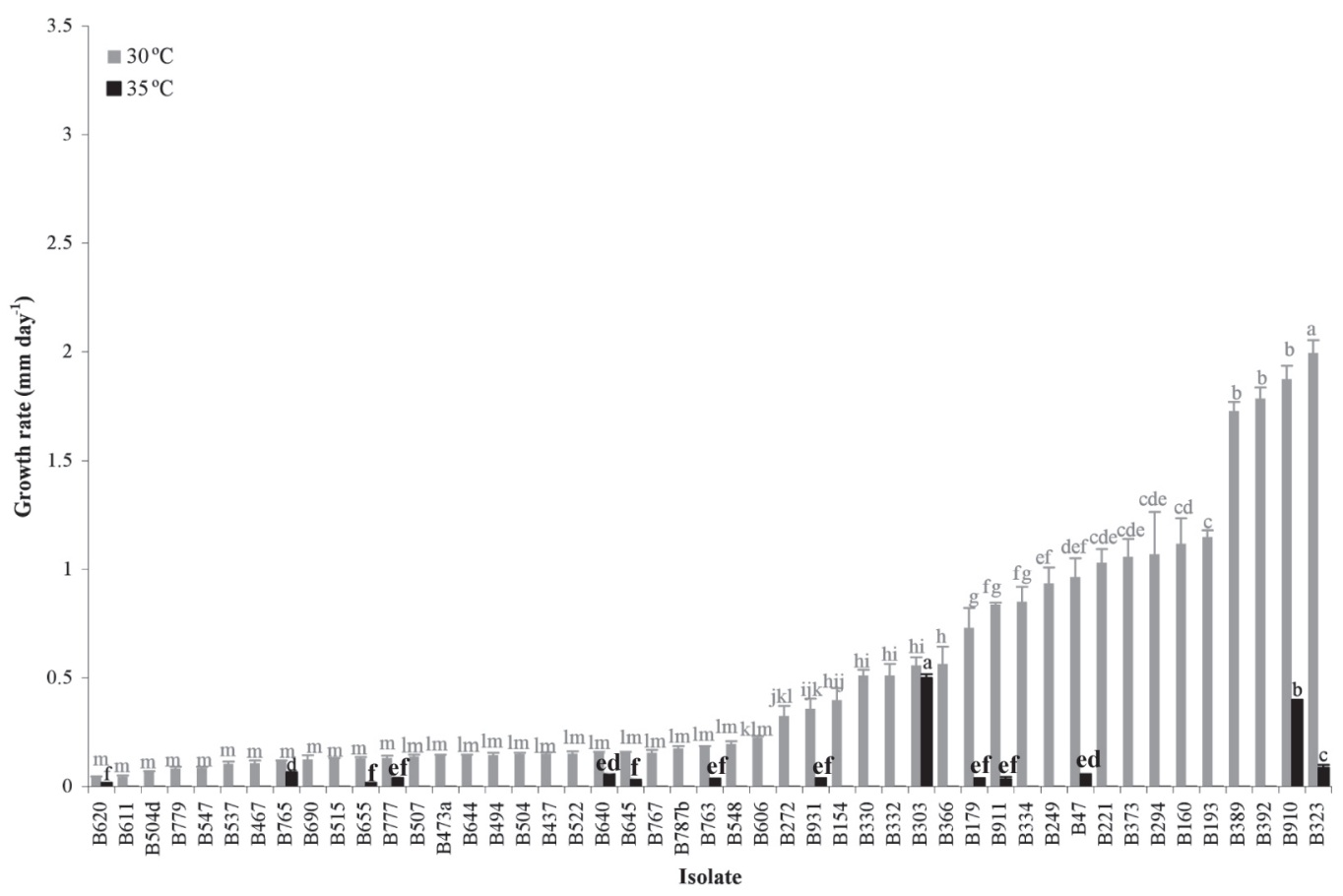

Distinct letters over the bars indicate differences according to Tukey test $(\mathrm{P}<0.05)$.

Figure 1. Colony growth rates of Beauveria bassiana isolates incubated at 30 and $35^{\circ} \mathrm{C}$.

Pringle (2003) who observed a decrease in radial growth of Beauveria isolates at $35^{\circ} \mathrm{C}$.

M. anisopliae presented development in all the colonies at $30{ }^{\circ} \mathrm{C}$, temperature at which the rates varied from 0.14 to $3.39 \mathrm{~mm} \mathrm{~d}^{-1}$, and with the greatest growth for Qu-M38 and Qu-M285 isolates $(\mathrm{P}<0.0001)$ (Figure 2). Incubation at $35{ }^{\circ} \mathrm{C}$ indicated that only 24 isolates could develop, with growth rates that varied from 0.017 to 2.17 $\mathrm{mm} \mathrm{d}^{-1}$. The Qu-M845 isolate showed the greatest radius $\left(2.17 \mathrm{~mm} \mathrm{~d}^{-1}\right)$ and was also one of those that best reacted to both temperatures. Qu-M984 and Qu-M256 were not affected by the rise in temperature $(\mathrm{P}<0.0001)$ while the rest statistically decreased their growth (Figure 2).

In this study, the growth response under the two evaluated temperatures varied considerably between isolates and species, this is how there was a greater quantity of de Metarhizium than Beauveria isolates that grew at 30 and $35{ }^{\circ} \mathrm{C}$. Ouedraogo et al. (1997) and Hallsworth and Magan (1999) also found that M. anisopliae has a wider growth range and a higher optimal temperature $\left(30{ }^{\circ} \mathrm{C}\right)$ than B. bassiana. Milner et al. (2002) found M. anisopliae isolates with rapid growth between 20 and $30^{\circ} \mathrm{C}$, with the greatest growth at $30^{\circ} \mathrm{C}$ and without growth at $35^{\circ} \mathrm{C}$.

Ouedraogo et al. (1997) point out that using pathogenic fungi as micopesticides needs various selection criteria, among them tolerance to different climatic contrasts and the possible effect of the pathogen-host interaction. In spite of the fact that thermal requirements vary with the fungal species and its ecological niche, optimal temperatures for development, pathogenicity, and survival are found between 20 and $30{ }^{\circ} \mathrm{C}$ (Tanada and Kaya, 1993). Only a limited number of species have an optimal development temperature greater than $35^{\circ} \mathrm{C}$ (Davidson et al., 2003).

In this case, thermal requirements of the studied fungal isolates as potential controllers of $V$. destructor are the temperatures existing in the brood area of the bee colonies. Just as Davidson et al. (2003) pointed out, our results indicate that the selected isolates grow at $35{ }^{\circ} \mathrm{C}$, and as a result could also function at peripheral temperatures of the brood area $\left(32.5-33.4{ }^{\circ} \mathrm{C}\right)$ where the mites preferably reproduce (Le Conte et al., 1990).

Bee colony temperature changes markedly between summer and winter. In the summer, temperatures depend more on the environment. The brood area is usually maintained from 32 to $37{ }^{\circ} \mathrm{C}$ while the rest of the beehive shows temperatures from 28 to $33{ }^{\circ} \mathrm{C}$. In winter, bees remain active to generate heat and stay together to reduce the rate of energy loss. In temperate regions, the winter temperature of the bee nest is normally maintained between 20 and $30{ }^{\circ} \mathrm{C}$ (Shaw et al., 2002). Although the evaluated temperatures have been based on the summer beehive conditions, it is considered that the selected isolates will also function under winter temperature conditions. 


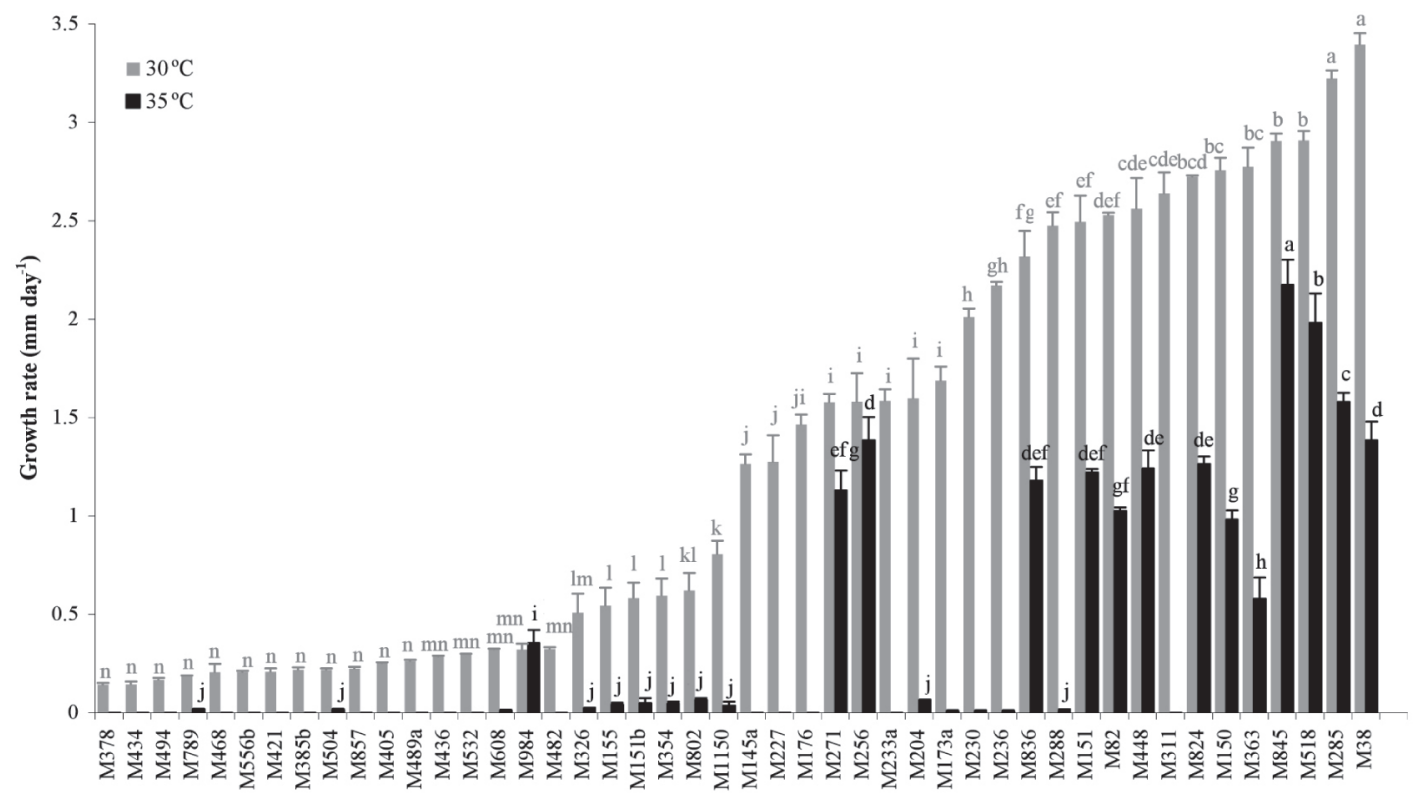

Isolate

Distinct letters over the bars indicate differences according to Tukey test $(\mathrm{P}<0.05)$.

Figure 2. Colony growth rates of Metarhizium anisopliae var. anisopliae isolates incubated at 30 and $35{ }^{\circ} \mathrm{C}$.

\section{Pathogenicity tests}

Two B. bassiana isolates caused varroa mortality $(20$ to $30 \%$ ) after 6 days of having been treated (Figure 3). Of the14 M. anisopliae isolates, 11 presented some degree of mortality in adult varroa. Only the Qu-M845 isolate achieved the highest sporulation percentage $(85 \%)$, followed by Qu-M271 and Qu-M488 with 60 and 50\%, respectively $(\mathrm{P}=0.0033)$ (Figure 3 ).

Differences in degrees of virulence of strains belonging to the same fungal species could be due to genetic variations arising from specialization toward a determined host and the geographical distribution of the strains (Alves, 1998; Coates et al., 2002). In this case, isolates belonged to soil samples of different geographical origins and were collected with Galleria mellonella L. (Lepidoptera: Pyrellidae) as insect bait (Goettel and Inglis, 1997) (Table 1).

Sporulation capacity of the fungus over its host is fundamental for the dissemination of the disease in field conditions allowing reinfestations from parasitized insects (Gottwald and Tedders, 1984). In accordance with the above-mentioned, the most promising isolate to control the pest could be M. anisopliae Qu-M845.

A period of mite mortality of 5 to 12 days was also observed for B. bassiana and 4 to 7 days for M. anisopliae. Meikle et al. (2006) reported a death period for mites between 5 and 10 days for $B$. bassiana and 4 to 7 days for $M$. anisopliae by using the same spore concentration as in this study. Meanwhile, Shaw et al. (2002) reported values of 2 to 3 days when using a concentration of $10^{8}$ conidia $\mathrm{mL}^{-1}$ and the immersion of the mites in this suspension; this application method can produce greater effectiveness of the fungus.

Numerous pathogens are known to infect mites and those found most frequently belong to the order Entomophorales. Common mite pathogens are of the Hirsutella and M. anisopliae genus (James, 2009). In the case of varroa control, a lot of research has been based on the use of pathogens of other arthropods, with the object of finding an appropriate fungal species or isolate that present high virulence in varroa. There is background information about an important group of Hirsutella thompsonii strains isolated from citrus mites, and many $M$. anisopliae isolates that have been isolated and stored, providing an important bank of potential strains to test on varroa (James, 2009). However, in their selection, as above-mentioned, these organisms must, in addition, adapt to the environmental conditions of the beehive in which they will be used (Sun et al., 2003).

Meikle et al. (2006; 2007) searching for varroa pathogens in beehives collected six B. bassiana isolates. However, subsequent tests confirmed that temperatures in the 30 to $32{ }^{\circ} \mathrm{C}$ range presented survival and germination problems of B. bassiana when the spore are applied in the beehives (Meikle et al., 2008). 
Although it is possible that the thermal requirements of the fungus change according to the development state such as conidia germination, formation of apresorio, penetration, vegetative growth, and host colonization, selection of the M. anisopliae Qu-M845 isolate based only on its vegetative growth at high temperatures (30 and $35^{\circ} \mathrm{C}$ ) might not be sufficient to ensure its functioning in the conditions inside the beehive, and consequently, its development as a microbial control agent requires future studies.

However, this isolate could have advantages if you consider that fungal spores can work directly through the cuticle. This is important since varroa is an ectoparasite that feeds by mouth suction for which it would be difficult to apply any pathogenic agent or toxin that need to pass through the intestine such as bacteria and virus. Furthermore, these fungi are easy to produce in artificial medium which is crucial to carry out a biological pest control strategy (James, 2009).

\section{CONCLUSIONS}

All the evaluated Beauveria bassiana and Metarhizium anisopliae var. anisopliae isolates showed growth at a temperature of $30^{\circ} \mathrm{C}$. However, at $35^{\circ} \mathrm{C}$, a reduction of the growth rates was observed in the isolates of both species, with the exception of three strains. Qu-M845 was the $M$. anisopliae strain with the greatest development at 35 ${ }^{\circ} \mathrm{C}$, as well as reaching high varroa mortality levels, fact which allows us to consider it as a potential controller of Varroa destructor. Pathogenic capacity and tolerance to environmental conditions to which it would be exposed inside the beehive allow us to consider it as a new alternative to control this pest. Nevertheless, new research studies are required to ensure its effectiveness in the field.

Table 1. Growth rates at 30 and $35{ }^{\circ} \mathrm{C}$ and geographical origin of Metarhizium anisopliae var. anisopliae (Qu-M) and Beauveria bassiana (Qu-B) isolates selected for pathogenicity tests on Varroa destructor.

\begin{tabular}{|c|c|c|c|c|}
\hline \multirow[b]{2}{*}{ Isolate } & \multirow[b]{2}{*}{$30^{\circ} \mathrm{C}$} & \multirow[b]{2}{*}{$35^{\circ} \mathrm{C}$} & \multicolumn{2}{|l|}{ Origin } \\
\hline & & & Location & $\begin{array}{c}\text { Geographical } \\
\text { coordinates }\end{array}$ \\
\hline & $\longrightarrow \mathrm{mm}$ & $\mathrm{d}^{-1} \longrightarrow$ & & \\
\hline Qu-M38 & $2.59 \pm 0.81^{1}(0.97)^{2}$ & $1.38 \pm 0.1(0.9)$ & Unknown & - \\
\hline Qu-M82 & $2.53 \pm 0.01(0.97)$ & $1.03 \pm 0.02(0.99)$ & El Carmen, Bío Bío Region & $36^{\circ} 48^{\prime} \mathrm{S}, 72^{\circ} 02^{\prime} \mathrm{W}$ \\
\hline Qu-M150 & $2.76 \pm 0.06(0.92)$ & $0.98 \pm 0.04(0.98)$ & Lago Chapo, Los Lagos Region & $41^{\circ} 25^{\prime} \mathrm{S}, 72^{\circ} 31^{\prime} \mathrm{W}$ \\
\hline Qu-M151 & $2.49 \pm 0.13(0.95)$ & $1.22 \pm 0.02(0.97)$ & Río Chamiza, Aysén Region & $45^{\circ} 23^{\prime} \mathrm{S}, 72^{\circ} 42^{\prime} \mathrm{W}$ \\
\hline Qu-M256 & $1.03 \pm 0.42(0.98)$ & $\begin{array}{l}1.38 \pm 0.12(0.92) \\
1.24 \pm 0.07 \mathrm{c}-\mathrm{f}\end{array}$ & Cañete, Bío Bío Region & $37^{\circ} 48^{\prime} \mathrm{S}, 72^{\circ} 23^{\prime} \mathrm{W}$ \\
\hline Qu-M271 & $1.19 \pm 0.39(0.97)$ & $1.11 \pm 0.13(0.9)$ & Coihueco, Bío Bío Region & $36^{\circ} 37^{\prime} \mathrm{S}, 71^{\circ} 49^{\prime} \mathrm{W}$ \\
\hline Qu-M285 & $3.67 \pm 0.39(0.94)$ & $\begin{array}{l}1.58 \pm 0.05(0.91) \\
0.97 \pm 0.11 \mathrm{efg}\end{array}$ & Lago Puyehue, Los Lagos Region & $40^{\circ} 43^{\prime} \mathrm{S}, 72^{\circ} 19^{\prime} \mathrm{W}$ \\
\hline Qu-M363 & $2.77 \pm 0.094(0.97)$ & $0.58 \pm 0.11(0.7)$ & Pinto, Bío Bío Region & $36^{\circ} 41^{\prime} \mathrm{S}, 71^{\circ} 53^{\prime} \mathrm{W}$ \\
\hline Qu-M448 & $2.56 \pm 0.15(0.97)$ & $\begin{array}{l}1.24 \pm 0.09(0.9) \\
1.38 \pm 0.12 b-\mathrm{e}\end{array}$ & Huape, Bío Bío Region & $36^{\circ} 36^{\prime} \mathrm{S}, 71^{\circ} 15^{\prime} \mathrm{W}$ \\
\hline Qu-M518 & $2.91 \pm 0.05(0.97)$ & $1.98 \pm 0.15(0.93)$ & Santa Bárbara, Bío Bío Region & $37^{\circ} 39^{\prime} \mathrm{S}, 72^{\circ} 01^{\prime} \mathrm{W}$ \\
\hline Qu-M824 & $2.73 \pm 0.00(0.96)$ & $\begin{array}{l}1.26 \pm 0.04(0.98) \\
1.58 \pm 0.05 \mathrm{a}-\mathrm{e}\end{array}$ & El Carmen, Bío Bío Region & $36^{\circ} 48^{\prime} \mathrm{S}, 72^{\circ} 02^{\prime} \mathrm{W}$ \\
\hline Qu-M836 & $2.02 \pm 0.33(0.96)$ & $1.18 \pm 0.11(0.96)$ & Villa Alegre, Maule Region & $35^{\circ} 39^{\prime} \mathrm{S}, 71^{\circ} 44^{\prime} \mathrm{W}$ \\
\hline Qu-M845 & $2.91 \pm 0.04(0.97)$ & $\begin{array}{l}2.17 \pm 0.13(0.9) \\
1.24 \pm 0.09 \mathrm{c}-\mathrm{f}\end{array}$ & Antuco, Bío Bío Region & $37^{\circ} 19^{\prime} \mathrm{S}, 71^{\circ} 40^{\prime} \mathrm{W}$ \\
\hline Qu-M984 & $0.32 \pm 0.03(0.9)$ & $0.35 \pm 0.07(0.9)$ & Quillota, Valparaíso Region & $32^{\circ} 51^{\prime} \mathrm{S}, 71^{\circ} 15^{\prime} \mathrm{W}$ \\
\hline Qu-B303 & $0.56 \pm 0.04(0.6)$ & $0.5 \pm 0.02(0.98)$ & Valle de Lluta, Arica and Parinacota Region & $17^{\circ} 14^{\prime} \mathrm{S}, 70^{\circ} 07^{\prime} \mathrm{W}$ \\
\hline Qu-B323 & $1.99 \pm 0.06(0.97)$ & $0.086 \pm 0.01(0.92)$ & Río Chaca, Arica and Parinacota Region & $18^{\circ} 26^{\prime} \mathrm{S}, 70^{\circ} 20^{\prime} \mathrm{W}$ \\
\hline Qu-B910 & $1.87 \pm 0.059(0.97)$ & $0.4 \pm 0.0002(0.6)$ & Easter Island & $27^{\circ} 07^{\prime} \mathrm{S}, 109^{\circ} 20^{\prime} \mathrm{W}$ \\
\hline
\end{tabular}




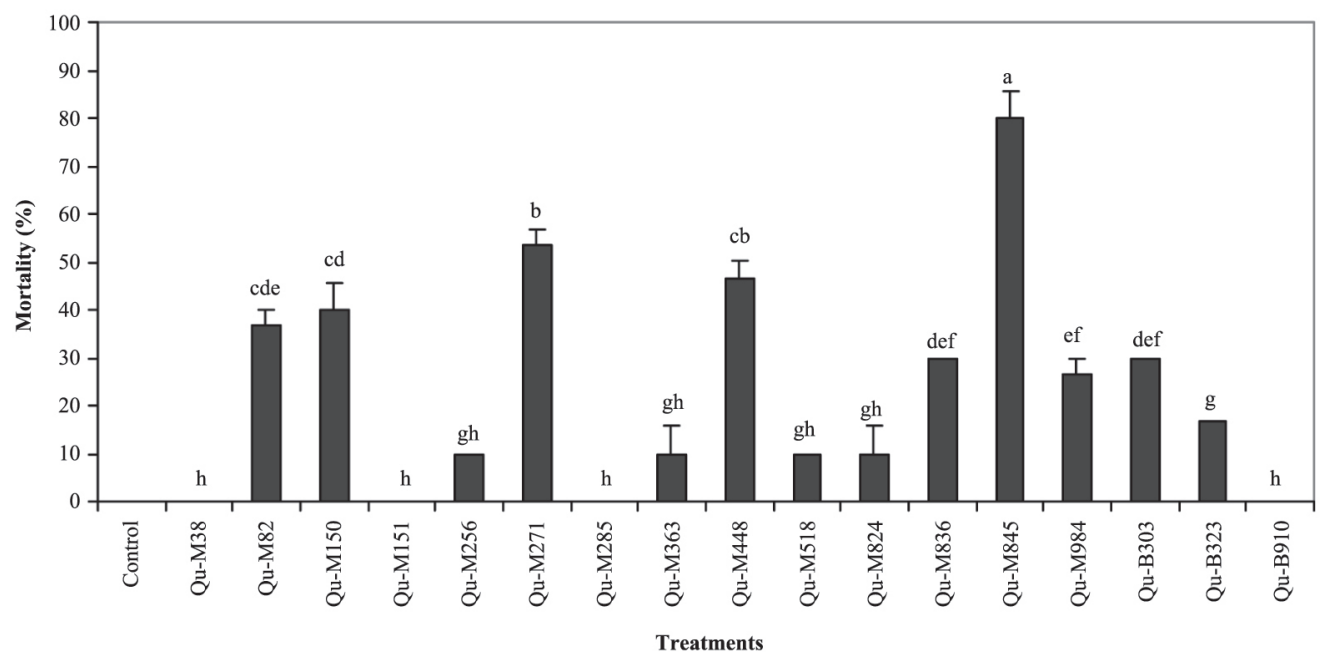

Distinct letters over the bars indicate differences according to Tukey test $(\mathrm{P}<0.01)$.

Figure 3. Mortality of Varroa destructor inoculated with different Metarhizium anisopliae var. anisopliae (Qu-M) and Beauveria bassiana $(\mathrm{Qu}-\mathrm{B})$ isolates.

\section{RESUMEN}

Selección de hongos entomopatógenos para el control de Varroa destructor (Acari: Varroidae). El objetivo de este trabajo fue seleccionar hongos entomopatógenos tolerantes a las temperaturas del nido de cría de las abejas (Apis mellifera), para ser utilizados en el control de Varroa destructor. Se evaluaron 50 aislamientos de Beauveria bassiana (Balsamo) Vuillemin y 48 de Metarhizium anisopliae (Metschn.) Sorokin a temperaturas de 30 y $35{ }^{\circ} \mathrm{C}$. Discos de agar de $5 \mathrm{~mm}$ de diámetro con micelio de colonias de cada aislamiento, se depositaron en el centro de placas Petri con medio agar Sabouraud dextrosa (ASD). Las placas fueron incubadas a 30 y 35 ${ }^{\circ} \mathrm{C}$ y oscuridad y diariamente se midió el radio de cada colonia. Todos los aislamientos de $B$. bassiana y $M$. anisopliae var. anisopliae presentaron una tendencia lineal a través del tiempo a temperaturas de incubación de $30{ }^{\circ} \mathrm{C}$. A $35{ }^{\circ} \mathrm{C}$ la mayoría de los aislamientos no crecieron, excepto tres aislamientos de B. bassiana y 14 de $M$. anisopliae ( $\mathrm{p}<0,001)$. Estos aislamientos fueron seleccionados para realizar pruebas de patogenicidad sobre V. destructor, aplicando una suspensión de $10^{7}$ conidias $\mathrm{mL}^{-1}$. El aislamiento más efectivo fue Qu-M845 de $M$. anisopliae ( $\mathrm{p}=0,0033$ ), produjo una mortalidad de $85 \%$. La capacidad patogénica de este aislamiento en $V$. destructor y su tolerancia a las condiciones ambientales a las que sería expuesto, permite considerar esta cepa como una alternativa de control para esta plaga.

Palabras clave: control biológico, temperatura, hongo entomopatógeno, Varroa destructor, varroasis.

\section{LITERATURE CITED}

Alves, S.B. 1998. Fungos entomopatogênicos. p. 289-381. In Alves, S.B. (ed.) Controle microbiano de insetos. 2a ed. Fundação de Estudos Agrários Luiz de Queiroz (FEALQ), Piracicaba, São Paulo, Brasil.

Anderson, D.L., and J.W.H. Trueman. 2000. Varroa jacobsoni (Acaro: Varroidae) is more than one species. Exp. Appl. Acarol. 24:165-189.

Calderone, N. 1999. Evaluation of formic acid and a thymol-based blend of natural products for the fall control of Varroa jacobsoni (Acari: Varroidae) in colonies of Apis mellifera (Hymenoptera: Apidae). J. Econ. Entomol. 92:253-260.

Coates, B., R. Hellmich, and L. Lewis. 2002. Allelic variation of a Beauveria bassiana (Ascomycota: Hypocreales) minisatellite is independent of host range and geographic origin. Genome 45:125-132.

Chandler, D., G. Dadidson, J. Pell, B. Vall, K. Shaw, and K. Sunderland. 2000. Fungal biocontrol of acari. Biocontrol Sci. Technol. 10:357-384.

Chandler, D., K.D. Sunderland, B.V. Ball, and G. Davison. 2001. Prospective biological control agents of Varroa destructor n. sp., an important pest of the European honeybee, Apis mellifera. Biocontrol Sci. Technol. 11:429-448.

Davidson, G.,K. Phelps, K. Sunderland, J.Pell, B.Ball, K.E. Shaw, and D. Chandler. 2003. Study of temperaturegrowth interactions of entomopathogenic fungi with potential for control of Varroa destructor (Acari: Mesostigmata) using a nonlinear model of poikilotherm development. J. Appl. Microbiol. 94:816-825. 
Goettel, M.S., and D.G. Inglis. 1997. Fungi: Hyphomycetes. p. 213-249. In Lacey, L.A. (ed.) Manual of techniques in insect pathology. Academic Press, London, UK.

Gottwald, T.R., and W.L. Tedders. 1984. Colonization, transmission and longevity of Beauveria bassiana and Metharhizium anisopliae (Deuteromycotina: Hypomycetes) on pecan weevil larvae (Coleoptera: Curculionidae) in the soil. Environ. Entomol. 13:557560.

Hallsworth, J.E., and N. Magan. 1999. Water and temperature relations of growth of the entomogenous fungi Beauveria bassiana, Metarhizium anisopliae and Paecilomyces farinosus. J. Invertebr. Pathol. 74:261-266.

Inglis, D., M. Goettel, T. Butt, and H. Strasser. 2006. Use of Hyphomycetous fungi for managing insect pests. $p$. 23-70. In Butt, T.M., et al. (eds.) Fungi as biocontrol agents. Progress, problems and potential. CABI Publishing, Wallingford, UK.

James, R. 2009. Microbial control for invasive arthropod pests of honey bees. p. 271-288. In Hajek, A., T. Glare, and M. O'Callaghan (eds.) Use of microbes for control and eradication of invasive arthropods. Springer Science, Dordrecht, The Netherlands.

Kanga, H.B.L., W.A. Jones, and R.R. James. 2003. Field trials using the fungal pathogen, Metarhizium anisopliae (Deuteromycetes: Hyphomycetes) to control the ectoparasitic mite, Varroa destructor (Acari: Varroidae) in honey bee, Apis mellifera (Hymenoptera: Apidae) colonies. J. Econ. Entomol. 96:1091-1099.

Le Conte, Y., G. Arnold, and P.H. Desenfant. 1990 Influence of brood temperature and hygrometry variations on the development of honey bee ectoparasite Varroa jacobsoni (Mesostigmata: Varroidae). Environ. Entomol. 19:1780-1785.

Lecuona, R.E., B. Papierok, y G. Riba. 1996. Hongos entomopatógenos. p. 35-60. In Lecuona, R.E. (ed.) Microorganismos patógenos empleados en el control microbiano de insectos plaga. Editorial Mariano Mas, Buenos Aires, Argentina.

Meikle, W.G., G. Mercadier, V. Girod, F. Derouané, and W.A. Jones. 2006. Evaluation of Beauveria bassiana (Balsamo) Vuillemin (Deuteromycota: Hyphomycetes) strains isolated from Varroa mites in Southern France. J. Apicul. Res. 45:219-220.
Meikle, W.G., G. Mercadier, N. Holst, and V. Girod. 2008. Impact of two treatment of a formulation of Beauveria bassiana (Deuteromycota: Hyphomycetes), conidia on Varroa mites (Acari: Varroidae) and on honey bee (Hymenoptera: Apidae) colony health. Exp. Appl. Acarol. 46:105-107.

Meikle, W.G., G. Mercadier, N. Holst, C. Nansen, and V. Girod. 2007. Duration and spread of an entomopathogenic fungus, Beauveria bassiana (Deuteromycota: Hyphomycetes), used to treat Varroa mites (Acari: Varroidae) in honey bee (Hymenoptera: Apidae) hives. J. Econ. Entomol. 100:1-10.

Melathopoulos, A., M. Winston, R. Whittington, T. Smith, C. Lindberg, A. Mukai, and M. Moore. 2000. Comparative laboratory toxicity of neem pesticides to honey bees (Hymenoptera: Apidae), their mite parasites Varroa jacobsoni (Acari: Varroidae) and Acarapis woodi (Acari: Tarsonemidae), and brood pathogens Paenibacillus larvae and Ascophaera apis. J. Econ. Entomol. 93:199-209.

Milner, R.J., P.A. Samson, and G.K. Bullard. 2002. FI1045: A profile of commercially useful isolate of Metarhizium anisopliae var. anisopliae. Biocontrol Sci. Technol. 12:43-58.

Ouedraogo, A., J. Fargues, M.S. Goettel, and C.J. Lomer. 1997. Effect of temperature on vegetative growth among isolates of Metarhizium anisopliae and $M$. flavoviride. Mycopathologia 137:37-43.

Shaw, K.E., G. Davidson, S.J. Clark, B.V. Ball, J.K. Pell, D. Chandler, and K.D. Sunderland. 2002. Laboratory bioassays to assess the pathogenicity of mitosporitic fungi to Varroa destructor (Acari: Mesostigmata), an ectoparasitic mite of the honeybee, Apis mellifera. Biol. Control 24:266-276.

Sun, J., J.R. Fuxa, and G. Henderson. 2003. Effects of virulence, sporulation, and temperature on Metarhizium anisopliae and Beauveria bassiana laboratory transmission in Coptotermes formosanus. J. Invertebr. Pathol. 84:38-46.

Tanada, Y., and H. Kaya. 1993. Fungal infections. p. 318-366. In Tanada, Y., and H. Kaya (eds.) Insect pathology. Academic Press, San Diego, California, USA.

Tefera, T., and K. Pringle. 2003. Germination, radial growth, and sporulation of Beauveria bassiana and Metarhizium anisopliae isolates and their virulence to Chilo partellus (Lepidoptera: Pyrilidae) at different temperatures. Biocontrol Sci. Technol. 13:699-704. 